\title{
QT dispersion, a simple tool to predict ventricular tachyarrhythmias and/or sudden cardiac death after myocardial infarction
}

\author{
Yoga Yuniadi, M Munawar, Budhi Setianto, Otte J Rachman
}

\begin{abstract}
Abstrak
Beberapa penelitian terdahulu menunjukkan kontradiksi hubungan antara dispersi QT dengan kejadian takiaritmia ventrikel dan atau kematian jantung mendadak. Penelitian-penelitian itu tidak mengeluarkan pengguna obat penghambat reseptor beta, bahkan pengguna obat tersebut merupakan mayoritas pada sampel mereka. Karena penggunaan penghambat reseptor beta sebagai pencegahan sekunder yang masih rendah di Pusat Jantung Nasional Harapan Kita, maka penelitian ini dilakukan untuk mengetahui hubungan antara dispersi QT dengan kejadian takiaritmia ventrikel dan atau kematian jantung mendadak pada pasien pascainfark. Interval QT, dispersi QT dan variabel klinis dibandingkan antara 36 orang pasien pascainfark yang mengalami takiaritmia ventrikel dan atau kematian jantung mendadak (kelompok kasus), dengan 75 pasien pascainfark yang tidak mengalami kedua kejadian tersebut (kelompok kelola). Dispersi QT yang lebih panjang (115 $\pm 41 \mathrm{msec}$ vs $81 \pm 25 \mathrm{msec}, p<0.001)$. Interval QT maksimal terkoreksi juga lebih panjang pada kelompok kasus $(534 \pm 56$ vs $501 \pm 35 \mathrm{msec}, p<0.001)$. Analisa regresi logistik menunjukkan adanya hubungan antara pemanjangan dispersi QT dengan kejadian takiaritmia ventrikel dan atau kematian jantung mendadak dengan RO 3,2, 4, dan 5,8 masing-masing untuk nilai potong 80, 90, dan 100 mdet. Dispersi QT dapat memprediksi kejadian takiaritmia ventrikel dan atau kematian jantung mendadak pada pasien infark miokard akut. Hasil ini menunjukkan bahwa dispersi QT tetap bermanfaat pada kondisi bebas pengaruh obat penghambat reseptor beta. (Med J Indones 2005; 14: 230-6)
\end{abstract}

\begin{abstract}
Recent studies showed contradictive results of the relation between QT dispersion and the occurrence of ventricular tachyarrhythmias and/or sudden cardiac death. In addition, beta adrenoreceptors blocking agents, which are known to decrease the incidence of lethal arrhythmias after myocardial infarction, administered to the majority of patients in those studies population. Since $\beta$-blocker as secondary prevention drug was underutilized at National Cardiovascular Center Harapan Kita, this study was performed to find out the relation between QT dispersion and ventricular tachyarrhythmias and/or sudden cardiac death after previous myocardial infarction. The QT interval duration, $Q T$ dispersion and clinical variables of 36 postinfarction patients with history of sustained ventricular tachyarrhythmias and/or sudden cardiac death (event group) were compared with 75 postinfarction patients without such events (control group). QT dispersion differed significantly between study groups and was increased in the event group (115 \pm 41 msec vs $81 \pm 25 \mathrm{msec}, p<0.001)$. Corrected maximal $Q T$ interval duration was also prolonged in the event group (534 $\pm 56 \mathrm{vs} 501 \pm 35$ msec, $p<0.001$ ). Regression analysis showed that increasing QT dispersion was related to the occurrence of ventricular tachyarrhythmias and/or sudden cardiac death with OR of 3.2, 4, and 5.8 for cut-off point of 80, 90, and 100 msec respectively. The QT dispersion could predict the occurrence of ventricle tachyarrhythmias and/or sudden cardiac death in patient with AMI. This study confirmed that the QTd remain useful in free of beta blocking agents state. (Med J Indones 2005; 14: 230-6)
\end{abstract}

Keyword : QT dispersion, Acute myocardial infarction, Sudden death.

Sudden cardiac death (SCD) is continuing as major problem in the management of heart disease. Approximately 400,000 Americans die suddenly each year, and it is the most common form of death in the

Department of Cardiology and Vascular Medicine, Faculty of Medicine University of Indonesia and National Cardiovascular Center Harapan Kita, Jakarta, Indonesia
United States. ${ }^{1}$ Among myocardial infarction (MI) patients discharge from hospital, $10 \%$ were die in the first year. One third of the deaths are sudden death, presumably due to ventricular arrhythmias. ${ }^{2}$ Adgey et $\mathrm{al}^{3}$, reported that when electrocardiogram was obtained within 4 minutes from the onset of symptoms of cardiac arrest, the majority of patients (91\%) exhibited ventricular fibrillation, which was consistent to the finding of Klein et al. ${ }^{4}$ Many efforts are perform to 
identify patients at risk of sudden death after acute myocardial infarction (AMI). Emerging data demonstrated that QT dispersion (QTd) is a new hope as a simple method to predict SCD after AMI. Unfortunatelly, such studies have difference and even contradictive results. $5,6,7,8,9,10$

Another issue is beta blocking agents. The majority of current studies did not exclude beta blocking agents users from their study population. ${ }^{5,9}$ Meanwhile, the MIAMI trial showed that beta blocking agents has been proven to decrease the incidence of ventricle fibrillation in AMI. ${ }^{11}$ Meta-analysis by Yusuf et $\mathrm{al}^{12}$ showed that beta blocking agents decrease the incidence of lethal arrhythmias by $15 \%$. Furthermore Singh et $\mathrm{al}^{13}$ showed beta adrenoreceptor agent may blunt circadian variation of QT interval. Therefore, it is ethically notworthy to design the study of post myocardial infarction patients by avoiding beta blocking agents administration. Meanwhile, the utility of beta blocking agents in acute myocardial infarction at National Cardiovascular Center Harapan Kita (NCCHK) was small. Yuniadi et al ${ }^{14}$ found only $13 \%$ acute MI patients were given beta blocking agents when discharged from NCC-HK.

The aim of this study is to elucidate the relation between QTd with ventricular tachyarrhythmia and/or sudden cardiac death after myocardial infarction without influence of beta blocking agents.

\section{METHODS}

The study design was retrospective case control study, held at NCC-HK. Study populations are all acute myocardial infarction patients who had been hospitalized at NCC-HK up to December 1997. Samples were divided into events group and control group. The event group consists of consecutive patients experienced of documented ventricular tachyarrhythmias and/or SCD $(n=36)$. The control group consists of all consecutive AMI patients without history of ventricular tachyarrhythmias and/or SCD $(n=75)$.

Inclusion criteria were as follow: all acute MI patients before 4 days from its onset, sudden cardiac death and/or ventricular tachyarrhythmias occur more than 48 hours from the onset of acute MI. Exclusions criteria were as follow: not in sinus rhythm, not adequate ECG recording for QT interval interpretation, an adequate ECG recording resulted after administration of antiarrhythmia drug class Ia or class III, administration of beta blocking agents, history of spontaneous ventricular tachycardia, bundle branch block, total AV block, QT interval can not be measured at leads aVL and V1, and premature beat bigemini.

Twelve-leads surface ECG of the second or third day from the onset of AMI was analyzed (Paper speed of $25 \mathrm{~mm} / \mathrm{s}$, gain of $10 \mathrm{mV} / \mathrm{mm}$ and sensitivity of 1). QT interval was measured using micrometer (Mitutoyo 6234474) and magnifying glass, then QTd, QT maximal (QTmax), QT minimal (QTmin) and its corrected value were calculated. Measurements were performed by single observer who was blind to events and control groups. Direct or telephone interview with patients, families, relatives or patient's doctor was done as necessary.

\section{Definition}

In this study AMI were defined as all AMI patients admitted to NCC-HK before 4 days from its onset. AMI was diagnosed if two of three following criterias fulfilled (WHO criterias); typical chest pain lasting more than 20 minutes, ST segment elevation in two contigous leads ( $2 \mathrm{~mm}$ in precordial leads or $1 \mathrm{~mm}$ in limb leads), and increase cardiac isoenzyme (CK-MB two fold of upper normal limit or more).

QT interval was measured from the onset of Q wave to the end of $T$ wave of standard 12 leads ECG recording. The clearest QT interval pattern from individual lead was choosen for measurement. In case of the presence of $\mathrm{U}$ wave that superimpose with $\mathrm{T}$ wave, the end of $\mathrm{T}$ wave was determine by extrapolation of deceleration slope to the isoelectric line. Correction of QT interval $(\mathrm{QTc}=$ corrected $\mathrm{QT}$ interval $)$ to the heart rate was performed using Bazett formula (QTc $=[1 / \sqrt{ } \mathrm{RR}] \mathrm{QT})$. Maximal value (QTmax) and minimal value (QTmin) of QT interval among 12 leads ECG of every subject were determined. Correction of QTmax and QTmin using Bazett formula were named as QTcmax and QTcmin respectively. QTd was defined as the difference between QTmax and QTmin.

Ventricular tachyarrhythmias were defined as documented sustained VT (lasting more than 30 seconds) or ventricle fibrillation (VF). Ventricular tachyarrhythmias characterized by sudden onset of symptoms, such as palpitations, dizziness, syncope, presyncope, convulsion or shortness of breath. SCD was defined if the death occur below 1 hour from the onset of symptoms of ventricular tachyarrhythmias or unwitnessed death. 


\section{Statistical Analysis}

Data analysis was performed using SPSS 11 software. Results are reported as mean \pm standard deviation. Differences of mean of QTd, QT max, QTcmax, QTmin and QTcmin between events and control group were analyzed by independent student $t$ test The corelation between QTd and ventricular tachyarrhytmia and/or SCD was determined by logistic regression. Rectifier Operating curve (ROC) was used to determine sensitivity and specificity of QTd cut-off point in predicting the events. A p value of $\leq 0.05$ was considered statistically significant.

\section{RESULTS}

\section{Clinical characteristics}

There were 154 consecutive AMI patients were observed during research period. Forty-three patients were administered antiarrhythmic drugs and/or beta blocking agent in early phase of AMI. Of 111 eligible patients, 36 (32\% with 29 male) experienced ventricular tachyarrhythmias and/or SCD and 75 (68\% with 70 male) were not. The mean age of events group was different with that of the control group $(\mathrm{p}=0.002)$.
More patients in the event group experienced of anterior infarction (62\% vs $43 \%$ ). Inferior infarction is less common in the event group ( $24 \%$ vs $41 \%$ ), but interestingly non $\mathrm{Q}$ wave infarction was happened more in the event group (14\% vs 9\%). The proportion of diabetes mellitus and hypertension patients were not different significantly between both groups. (Table 1)

\section{Electrocardiogram Variables}

Patients who experienced ventricular tachyarrhythmias or died suddenly after previous myocardial infarction demonstrated significant longer QTd than controls group (115 $\pm 41 \mathrm{msec}$ vs $81 \pm 25 \mathrm{msec}$ respectively, $\mathrm{p}<0.001)$. The QTmax absolute value was not different between events group and control group (435 \pm 61 vs $436 \pm 39$ msec respectively, $\mathrm{p}=0.904$ ) but its corrected value was different significantly between both groups (534 \pm 56 vs $501 \pm 35 \mathrm{msec}, \mathrm{p}<0.001)$. In contrast, the absolute value of QTmin was different significantly between events and control group ( $319 \pm 47$ vs $354 \pm 37$ msec respectively, $\mathrm{p}<0.001)$ but not different statistically among its corrected value $(391 \pm 34$ vs $402 \pm 54$ msec respectively, $\mathrm{p}=0.258$ ). (Table 2 )

Table 1. Clinical characteristics

\begin{tabular}{lccc}
\hline \multicolumn{1}{c}{ Characteristics } & Events $(\mathbf{n = 3 6})$ & Control $(\mathbf{n}=\mathbf{7 5})$ & $\mathbf{p}$ \\
\hline Female & $7(19 \%)$ & $5(7 \%)$ & $\mathrm{NS}$ \\
Male & $29(81 \%)$ & $70(93 \%)$ & $\mathrm{NS}$ \\
Age & $61 \pm 9$ yo & $55 \pm 8$ yo & 0.002 \\
Infarct location & & & \\
1. Anterior & $62 \%$ & $43 \%$ & \\
2. Inferior & $24 \%$ & $41 \%$ & \\
3. Anteroseptal & 0 & $6 \%$ & \\
4. Non Q & $14 \%$ & $9 \%$ & $\mathrm{NS}$ \\
5. Others & 0 & $1 \%$ & $\mathrm{NS}$ \\
Diabetes Mellitus & $10(28 \%)$ & $19(25 \%)$ & \\
Hypertension & $16(44 \%)$ & $28(37 \%)$ & \\
\hline
\end{tabular}

NS = not significant

Table 2. Univariate Analysis of Electrogram Variables

\begin{tabular}{lccc}
\hline \multicolumn{1}{c}{ Variables } & Events & Control & p \\
\hline HR & $93 \pm 17 \mathrm{bpm}$ & $81 \pm 13 \mathrm{bpm}$ & $<0.001$ \\
QT max & $435 \pm 61 \mathrm{msec}$ & $436 \pm 39 \mathrm{msec}$ & $\mathrm{NS}$ \\
QTc max & $534 \pm 56 \mathrm{msec}$ & $501 \pm 35 \mathrm{msec}$ & $<0.001$ \\
QT min & $319 \pm 47 \mathrm{msec}$ & $354 \pm 37 \mathrm{msec}$ & $<0.001$ \\
QTc min & $391 \pm 34 \mathrm{msec}$ & $402 \pm 54 \mathrm{msec}$ & $\mathrm{NS}$ \\
QTd & $115 \pm 41 \mathrm{msec}$ & $81 \pm 25 \mathrm{msec}$ & $<0.001$ \\
\hline
\end{tabular}

$\mathrm{HR}=$ heart rate, bpm = beat per minute, QTmax = Maximal value of QT interval, QTcmax = corrected QTmax using Bazett formulae, $\mathrm{QTmin}=$ minimal value of QT interval, $\mathrm{QTcmin}=$ corrected $\mathrm{QTmin}$ using Bazett formulae, $\mathrm{QTd}=\mathrm{QT}$ dispersion, $\mathrm{msec}=$ millisecond, NS = not significant. 
No significant different of QTd in patients with diabetes mellitus and hypertension compare to that without those conditions ( $95 \pm 35$ vs $91 \pm 35 \mathrm{msec}$ and $92 \pm 35$ vs $92 \pm 35 \mathrm{msec}$, respectively). Thrombolytic therapy did not influence QTd value in overall patients ( $88 \pm 33$ vs $97 \pm 37$ msec between with and without therapy respectively).

Univariate logistic regression analysis showed that QTd could predict the occurrence of ventricular tachyarrhythmias and/or sudden cardiac death, with OR of $3.2(\mathrm{p}=0.011, \mathrm{CI} 95 \% 1.30-8.00), \quad 4.0(\mathrm{p}=$ 0.001 CI95\% 1.72-9.29) and $5.8(\mathrm{p}<0.001$, CI95\% 2.43-13.80) for cut off point of 80, 90 dan $100 \mathrm{~ms}$, respectivelly. Others parameter which significanty predict the event occurrence were QTcmax, QT min and heart rate. Multiple logistic regression analysis showed that only QTd and heart rate significantly predicted the events occurrence.

ROC analysis of QTd showed that $118.4 \mathrm{msec}$ is the most appropriate cut-off point with sensitivity of $37.7 \%$ (95\% CI $24.8-52.1$ ) and specificity of $94.1 \%$ (95\% CI 87.5 - 97.8) (Figure 1). Sensitivity and specificity value for other cut-off point were respectively $69.8 \%$ and $47.5 \%$ for $80 \mathrm{msec}, 58.5 \%$ and $66.3 \%$ for $90 \mathrm{msec}$, and $50.9 \%$ and $76.2 \%$ for $100 \mathrm{msec}$.

\section{DISCUSSION}

\section{QT dispersion}

This case control study showed that QTd value is longer in patients who experienced ventricular tachyarrhythmias and/or SCD after MI. This finding is consistent with recent studies from Perkiomaki, et $\mathrm{al}^{5}$ and Zareba et al. ${ }^{15}$ Furthermore, our results confirmed that in beta blocking agent free state, the prolongation of QTd in AMI setting could predict the occurrence of ventricular tachyarrhythmias and/or SCD.

QTd is a representation of regional repolarization inhomogenity and its presence will easily activated the reentry circuit. It has been proven that reentry is a major mechanism of ventricular tachyarrhythmias in chronic myocardial infarction patients. ${ }^{5}$ In this study, the major mechanism of ventricular tachyarrhythmias was probably due to reentry mechanism as we only select patients beyond 48 hours from onset of AMI. Ventricular tachyarrhythmias due to automaticity usually occur in the first $24-48$ hours of acute MI. ${ }^{16,17}$ This study support the postulation that QTd is a predictor of reentrant ventricular tachyarrhythmias.
We performed standard ECG recording using paper speed of $25 \mathrm{~mm} / \mathrm{s}$ to measure all study parameters because such paper speed is a standard practice of ECG recording in the world. Then, we hope that the results of this study would be applicable directly in daily practice. Eventhough Van de Loo, et al ${ }^{18}$ found paper speed of 100 or $50 \mathrm{~mm} / \mathrm{s}$ result in less variably measurement, other authors ${ }^{6,15}$ obtained a good result with paper speed of $25 \mathrm{~mm} / \mathrm{s}$. Measurement of QT interval was perfomed by a single experienced observer blinded to events and control groups, which will omit inter-observer variation. In addition, it has been proven that intra and inter observer variation of QTd measurement either with manual or automatic method were acceptable. ${ }^{5,18}$ Single observer was frequently used to measure QT interval in current studies. ${ }^{15,19,20,21}$ Since the observer blind to events and control group, differences value resulted from measurement might not due to measurement bias. ${ }^{21}$

QTd of patients with hypertension or diabetes mellitus was not different statistically than patients without such diseases. QTd correlates with left ventricle mass. Hypertensive patients without left ventricle hypertrophy have normal QTd and shorter than that with left ventricle hypertrophy. ${ }^{22}$ Diabetes mellitus patients with autonomic neuropathy have prolong QTd, while patients without autonomic dysfunction have similar QTd value with normal responders. ${ }^{23}$ Probably diabetes mellitus patients in this study have not yet suffered from autonomic neuropathy. There was significant different of mean age between the events and control group. Age was differently reported in term of its influence to QTd. Bortolan et $\mathrm{al}^{24}$ studied the QTd in three groups of patients who were healthy, had only cardiac disease, and had only hypertension in term of age ( $<75$ and $>75$ yo) and gender. The study showed that age and gender influence the QTd differently in the three groups. QTd indices were influenced in the healthy group by gender $(\mathrm{p}<0.001)$, in the cardiac disease group by age $(\mathrm{p}<0.01)$, and in hypertension group by age $(\mathrm{p}<0.02)$ and gender $(\mathrm{p}<0.01)$.

Corrected QT maximal interval of events group was longer significantly than control group, but was not happened to its absolute value. Prolongation of QT interval usually occur at acute phase of myocardial infarction $^{25}$ and has long been recognized as an important factor in association with fatal ventricular arrhythmias, either at acute phase ${ }^{26}$ or at post infarction peroid. ${ }^{27}$ Zabel, et $\mathrm{al}^{28}$ showed that QT interval influenced by heart rate, which was shorter at higher heart rate and vice versa, but it did not happen to QT 
dispersion. Thus, corrected QTmax should be considered more than its absolute value. In the prospective study, Ahnve, et $\mathrm{al}^{29}$ measured QT interval when pateints discharge from hospital, and found that during 1 year follow up, dead patients had larger QT interval than that of survivors. They conclude the corrected QT interval measured at discharge time may predict one year prognostic. In our study, multivariate analysis did not show the significant of QTcmax as a predictor of events.

It has long been recognized that heart rate influences the prognosis of AMI patients. Mauss et al, recently performed study of 432 consecutive survivors of AMI and found that heart rate assessed from the standard 12-lead ECG ( chi2 7.1, P = .008) together with LVEF ( chi2 $11.4, \mathrm{P}=.0007$ ), and age ( chi $29.2, \mathrm{P}=.02$ ), as independent risk parameters for future mortality and arrhythmic events. ${ }^{30}$ In this study, heart rate was counted from 12-lead ECG recorded on day 2 or 3 from the onset of AMI which was different from Mauss's study who counted from discharge ECG. However, both recording time has similar autonomic state as the very acute phase of MI already passed.

\section{Beta blocking agent and QT dispersion}

Among beta blocking agents users which was excluded from this study, there were $19 \%$ who experienced events and $21 \%$ without events. These numbers were very small proportion compare to that of recent reports which were around $67 \%-83 \%$. $^{5,9}$

Recent prospective study by Zabel, et $\mathrm{al}^{9}$ showed no relation between QT dispersion and mortality or arrhythmias events, but the majority of their study populations $(83 \%)$ took beta blocking agent therapy. The negative relation between QTd with mortality and arrhythmic events presumably was influenced by higher beta blocking agent's utility. Unfortunatelly, they did not analyze the difference of QTd between patients with and without beta blocking agents. The effects of beta blocking agents on malignant and potentially lethal ventricular arrhythmias are a prime concern. In the MIAMI trial (Metoprolol in Acute Myocardial Infarction) ${ }^{11}$ little difference was noted in the incidence of ventricular fibrillation in the first few days, but from day 6 to the end of the trial on day 15 the total number of episodes was reduced from 54 with placebo to 24 with metoprolol. In another metoprolol trial $^{31}$ using oral therapy, a significant reduction was observed in the incidence of ventricular fibrillation during the hospital phase (17 of 698 controls vs 6 of 697 treated). A meta-analysis of almost 30 trials of all intravenous beta blocking agents suggest a decrease in potentially lethal arrhythmias of $15 \% .^{12}$ At least 11 trials showed a reduction in the incidence of sudden cardiac death (mean of 31\%) as a result of beta blocking agents involving five different agents. ${ }^{32}$ Recent study by Singh, et $\mathrm{al}^{13}$ showed a reduction in circadian variation of QT interval especially around wake up hours, by giving atenolol $50 \mathrm{mg} /$ day or metoprolol 25 $\mathrm{mg}$ b.i.d. The lower the QT interval variation, the smaller the QT dispersion value and it means more homogen of regional repolarization variation. Therefore, study of QTd after AMI without excluding beta blocking agent user is questionable. Our results confirmed the benefit of QTd to predict arrhythmics event in AMI patients whom beta blocking agents were not administered.

\section{Effects of thrombolytic therapy to ventricular tachyarrhytmias and sudden cardiac death}

Early thrombolytic therapy was proven to decrease risk of ventricle fibrillation in the acute phase of myocardial infarction. ${ }^{33}$ Although no prospective data available, the incidence of sudden cardiac death was decrease with early reperfusion. A retrospective analysis among reperfused patients, either spontaneous or with thrombolytics, which were proven by catheterization, none of them suffered from sudden cardiac death, in contrast to $18 \%$ of patients without reperfusion. ${ }^{34}$ Meta analysis of 15 randomized trials by Solomon, et $\mathrm{al}^{35}$ reported early and in hospital ventricle fibrillation of patients with thrombolytics therapy were smaller than pacebo group. It is assumed that the reduction of arrhythmic substrate by successful revascularization may decrease repolarization inhomogenity at the jeopardize area, due to restoration of ischaemi and normalization of transmembrane electromechanical gradien. In this study QT dispersion of patients with thrombolytic therapy was not different significantly than that without such drug, suggesting the occurrence of arrhythmic death had multifactorial role not only inhomogenity of repolarization.

\section{CONCLUSION}

The QTd could predict the occurrence of ventricle tachyarrhythmias and/or SCD in patient with AMI. 
This study confirmed that the QTd still useful in beta blocking agents free state.

\section{Study limitations}

The QT interval measurement in this study was performed using manual method. Eventhough reproducibility of manual measurement was acceptable ${ }^{9,14,36}$ but automatic measurement result in better reproducibility. ${ }^{6}$ Computer based automatic measurement of QT dispersion give a better results, especially if the measurement is performed by a single observer. ${ }^{5,18}$

\section{REFERENCES}

1. Fogoros RN. The electrophysiology study in the evaluation of ventricular tachyarrhythmias. In: Fogoros $\mathrm{RN}$, editor. Electrophysiologic testing. $1^{\text {st }}$ ed. Boston: Blackwell Scientific Publications; 1991.p. 159-208.

2. Multicenter Postinfarction Research Group. Risk stratification and survival after myocardial infarction. $\mathrm{N}$ Engl J Med 1983; 309: 331-6.

3. Panidis IP, Morganroth J. Iniating events of sudden cardiac death. In: Josephson ME, Brest AN, eds. Sudden cardiac death. Cardiovascular clinics. Philadelphia: FA Davies Co; 1985.p. 81-92.

4. Klein RC, Vera Z, Mason DT et al. Ambulatory holter monitor documentation of ventricular tachyarrhythmia as mechanism of sudden death in patients with coronary artery disease. Circulation 1983; 68: 7A(abst).

5. Perkiomaki JS, Koistinen MJ, Yli-Mayry $S$ et al. Dispersion of QT interval in patients with and without susceptibility to ventricular tachyarrhythmias after previous myocardial infarction. J Am Coll Cardiol 1995; 26: 174-9.

6. Glancy JM, Weston PJ, Bhullar HK. Reproducibility and automatic measurement of QT dispersion. Eur Heart J 1996; 17: 1035-9.

7. Zareba W, dan Moss AJ. QT duration and dispersion do not predict outcome patients with inducible ventricular tachycardia: Experience from the multicenter automatic defibrillator implantation trial. Circulation 1997 (Suppl-I); 96: I-77 (abst).

8. Higham PD, Furnis SS, Campbell RW. QT dispersion and components of QT interval in ischaemia and infarction. Br Heart J 1995; 73: 32-6.

9. Zabel M, Klingenheben T, Franz MR et al. Assessment of QT dispersion for prediction of mortality or arrhythmic events after myocardial infarction. Results of a prospective, long-term follow-up study. Circulation 1998; 97: 2543-50

10. Perkiomaki JS, Huikuri HV, Koistinen JM et al. Heart rate variability and dispersion of QT interval in patients with vulnerability to ventricular tachycardia and ventricular fibrillation after previous myocardial infarction. J Am Coll Cardiol 1997; 30: 1331-8.
11. The MIAMI trial research group. Metoprolol in acute myocardial infarction (MIAMI). A randomized placebocontrolled international trial. Eur Heart J 1985; 6: 199-226.

12. Held PH dan Yusuf S. Effects of $\beta$-blockers and calcium channel blockers in acute myocardial infarction. Eur Heart J 1985; 14(suppl.F): 18-25.

13. Singh JP, Musialek P, Sleight $P$ et al. Effect of atenolol or metoprolol on waking hour dynamics of the QT interval in myocardial infarction. Am J Cardiol 1998; 81: 924-6.

14. Yuniadi Y, AS Fajri M, Syukri M et al. Dispersi QT pada infark miokard akut di Rumah Sakit Jantung Harapan Kita. J Kardiologi Indonesia 1999 ; 24 : 154 - 9.

15. Zareba W, Moss JA, Cessie le Saskia. Dispersion of ventricular repolarization and arrhythmic cardiac death in coronary artery disease. Am J Cardiol 1994; 74: 550-3.

16. Campbell RWF. Arrhythmias. In: Julian DG, Braunwald E, eds. Management of acute myocardial infarction. $1^{\text {st }}$ ed. London: WB Saunders Co;1994.p. 223-40.

17. Josephson ME, Callans DJ. Sustained ventricular tachycardia. In: Ref. 5: 336-62.

18. Van de Loo A, Arendts W, Hohnloser SH. Variability of QT dispersion measurements in the surface electrocardiogram in patients with acute myocardial infarction and in normal subjects. Am J Cardiol 1994; 74: 113-8.

19. Wei K, Dorian P, Newman D et al. Association between QT dispersion and autonomic dysfunction in patients with diabetes mellitus. J Am Coll Cardiol 1995; 26: 859-63.

20. Fu GS, Meissner A, Simon R et al. Repolarization dispersion and sudden cardiac death in patient with impaired left ventricular function. Eur Heart J 1997; 18: 281-9.

21. Bogun F, Chan K, Harvey M, et al. QT dispersion in nonsustained ventricular tachycardia and coronary artery disease. Am J Cardiol 1996; 77: 256-9.

22. Ichkhan K, Molnar J, Samberg J. Relation of left ventricular mass and QT dispersion in patients with systematic hypertension. Am J Cardiol 1997; 79: 508-11.

23. Shimabukuro $M$, Chibana $T$, Yoshida $H$ et al. Increased QT dispersion and cardiac adrenergic dysinnervation in diabetic patients with autonomic neuropathy. Am J Cardiol 1996; 78: 1057-9.

24. Bortolan G, Bressan M, Golferini F. ILSA Study Group. QT dispersion in the elderly. The ILSA Study. Aging Clin Exp Res 2004; 16: $342-8$.

25. Cinca J, Figueras J, Tenorio L et al. Time course and rate dependence of QT interval changes during noncomplicated acute transmural myocardial infarction in human beings. Am J Cardiol 1981; 48: 1023.

26. Ahnve S, Lundman T, Shoaleh var M. The relationship between QT interval and ventricular arrhythmias in acute myocardial infarction. Acta Med Scand 1978; 204: 17 (abst).

27. Moller M. QT interval in relation to ventricular arrhythmias and sudden cardiac death in postmyocardial infarction patients. Acta Med Scand 1981; 210: 73 (abst).

28. Zabel $M$, Franz $M R$, Klingenheben $T$ et al. Rate dependence of the QT interval and of QT dispersion: Comparison of atrial pacing and exercise testing. Circulation 1997; 96(Supl): I-325(abst).

29. Ahnve S, Gilpin E, Madsen EB et al. Prognostic importance of QTc interval at discharge after acute 
myocardial infarction: A multicenter study of 865 patients. Am Heart J 1984; 108: 395-400.

30. Mauss O, Klingenheben T, Ptaszynski P, Hohnloser SH. Bedside risk stratification after acute myocardial infarction: prospective evaluation of the use of heart rate and left ventricular function. J Electrocardiol. 2005; 38: 106-12.

31. Ryden L, Ariniego R, Arnman K et al. A double-blind trial of metoprolol in acute myocardial infarction: effects on ventricular tachyarrhythmias. N Eng J Med 1983; 308: 614-18.

32. Chamberlain D. $\beta$-blockers and calcium antagonists. In: Ref. 16: 193-221.

33. Volpi A, Cavalli A, Santoro E et al. The GISSI Investigators. Incidence and prognosis of secondary ventricular fibrillation in acute myocardial infarction: evidence for a protective effect of thrombolytic therapy. Circulation 1990; 82: 1279-88.

34. Cigarroa RG, Lange RA, Hillis LD. Prognosis after acute myocardial infarction in patients with and without residual anterograde coronary blood flow. Am J Cardiol 1989; 64: 155-60.

35. Solomon SD, Ridker PM, Antman EM. Ventricular arrhythmias in trials of thrombolytic therapy for acute myocardial infarction. A meta analysis. Circulation 1993; 88: $2575-81$.

36. Fei L, Statters DJ, Camm AJ. QT interval dispersion on 12-lead electrocardiogram in normal subject: its reproducibility and relation to the $\mathrm{T}$ wave. Am Heart $\mathbf{J}$ 1994; 127: 1654-5. 